\title{
Pain-induced depression is related to overestimation of sleep quality in a very elderly population with pain
}

\author{
Depressão-dor induzida está relacionada à superestimação da qualidade do sono em \\ longevos com dor
}

Ricardo Humberto Felix ${ }^{1,2}$, Carla Bezerra Lopes Almeida' ${ }^{1}$ Renata Carvalho Cremaschi2,3, Fernando

Morgadinho Coelho ${ }^{2,3}$, Fânia Cristina Santos ${ }^{1}$

\begin{abstract}
Objective: To study the quality of sleep in very elderly people with chronic pain. Methods: We investigated 51 very elderly people without dementia and with chronic pain according to the Geriatric Pain Measure. Katz and Lawton questionnaires were used to evaluate functionality. The Geriatric Depression Scale and Geriatric Psychosocial Assessment of Pain-induced Depression were also used. Self-perceptions of sleep and quality of sleep were checked using the Pittsburgh Sleep Quality Index. Results: Moderate pain was seen in $64.7 \%$ participants. The tracking of depression was positive for $41.2 \%$. Poor quality of sleep was noted in $49 \%$ of them, but $82.3 \%$ perceived that they had a very good, or a good, sleep. The main factors associated with poor sleep quality were measurement of pain, self-perception of sleep, and pain-induced depression. Conclusion: Very elderly people with chronic pain, and without dementia, had a higher prevalence of poor sleep; however, they overestimated their sleep quality. Poor quality of sleep was associated with a poor self-perception of sleep and pain-induced depression.
\end{abstract}

Keywords: chronic pain; sleep; aging; aged.

\section{RESUMO}

Objetivo: Estudar a qualidade do sono em longevos com dor crônica. Métodos: Foram investigados 51 longevos sem demência e com dor crônica de acordo com o Geriatric Pain Measure. Os questionários de Katz e Lawton foram utilizados para avaliar a funcionalidade. Para o rastreio de depressão foram usados o Geriatric Depression Scale e Geriatric Psychosocial Assessment of Pain-induced Depression. Auto-percepção e qualidade do sono, de acordo com o Pittsburgh Sleep Quality Index, também foram verificados. Resultados: Dor moderada foi observada em $64,7 \%$ dos participantes. 0 rastreamento de depressão foi positivo para 41,2\% da amostra. Má qualidade do sono foi observada em $49 \%$ deles, entretanto $82,3 \%$ dos participantes tiveram uma muito boa ou boa auto-percepção do sono. Os principais fatores associados à má qualidade do sono foram mensuração da dor, auto-percepção ruim do sono e depressão induzida por dor. Conclusão: Os longevos com dor crônica e sem demência apresentam maior prevalência de sono de má qualidade, entretanto com superestimação desta. A má qualidade do sono foi associada com auto-percepção do sono ruim e depressão induzida por dor.

Palavras-chave: dor crônica; sono; envelhecimento; idoso.

Sleep disorders and chronic pain are public health problems leading to significant functional and social impact on aging $^{1}$. Pain, chronic diseases, psychiatric illnesses, use of medications, and primary sleep disorders are prevalent in very elderly people resulting in impairment of the quality of their sleep ${ }^{23}$.

Many clinical conditions are associated with pain and aging. Osteoarthritis, rheumatoid arthritis, and neurologic disorders cause persistent pain resulting in disability, depression, social isolation, fatigue, and sleep complaints ${ }^{3}$. Over $70 \%$ of older people have chronic pain leading to impairment of activities of daily life ${ }^{4,5,6}$.

Although the prevalence of sleep disorders in patients with chronic pain ranges between $50 \%$ and $88 \%$, the perception of this issue is poor ${ }^{7}$. Being deprived of sleep increases pain and pain impairs sleep quality. Poor sleep quality gives rise to

\footnotetext{
${ }^{1}$ Universidade Federal de São Paulo, Disciplina de Geriatria e Gerontologia, Serviço de Dor e Doenças Osteoarticulares, São Paulo SP, Brasil;

${ }^{2}$ Universidade Federal de São Paulo, Departamento de Psicobiologia, Ambulatório de Sonolência Excessiva Diurna, São Paulo SP, Brasil;

${ }^{3}$ Universidade Federal de São Paulo, Departamento de Neurologia e Neurocirurgia, São Paulo SP, Brasil.

Correspondence: Fernando Morgadinho Santos Coelho; Rua Marselhesa, 529; 04020-060 São Paulo SP, Brasil; E-mail: fernandomorgadinho@hotmail.com Conflict of interest: There is no conflict of interest to declare.

Received 12 June 2016; Received in final form 14 August 2016; Accepted 28 September 2016.
} 
metabolic and cardiovascular morbidities, as well as impairing social interaction with a subsequent higher risk of mortality ${ }^{7}$.

However, many old people and their families believe that pain is a regular symptom of aging and they are reluctant to talk about it to avoid procedures, medications, and side effects of possible treatments ${ }^{8}$.

Nowadays, pharmacological and non-pharmacological treatments for the control of pain and sleep disorders are much more accessible. However, the quality of sleep and chronic pain in the very elderly population are still underestimated ${ }^{7}$.

Depression, sleep, and dementia have an intrinsic relationship. Cognitive symptoms due to severe depression are real, as well as symptoms of depression being common in patients with dementia. Indeed, sleep disturbances in late-life, depressed patients may also predict poorer cognitive functioning. There are few studies on chronic pain and sleep in the elderly population without dementia. It is important to highlight this issue to check whether all resources to improve pain and sleep in this population are being properly used ${ }^{7}$.

This paper studies the perception of, and quality of sleep, in very elderly people with chronic pain and without dementia.

\section{METHODS}

This was a cross sectional study approved by Ethics Committee at Universidade Federal de São Paulo - Unifesp (CEP No. 072353/2014). All participants signed an informed consent. The population came from the cohort of healthy elderly individuals at the geriatric division at UNIFESP, which studied very elderly patients (80 years or older) living in a community, in the city of São Paulo 9 .

Very elderly patients with pain for more than six months and an intensity of three or more, as recommended by the International Association for the Study of Pain and the Verbal Rating Scale (pain assessment), were invited to participate in the study ${ }^{10}$.

Cognitive impairment was excluded by following up in a regular cohort for two years or more. Renal failure, chemotherapy, radiotherapy, hospitalization in the previous three months, and a neoplastic etiology of pain were exclusion criteria9.

We studied 51 very elderly people without dementia and with chronic pain, (87.5 \pm 4.31 years), 41 (80.4\%) women, 39 (76.5\%) Caucasians, 29 (56.9\%) widowed, and 39 (76.5\%) patients with little education. Of the sample, 34 individuals $(66.7 \%)$ had a sedentary lifestyle, 36 participants $(70.6 \%)$ had between three and six diseases under treatment, and 39 of them $(76.5 \%)$ used multiple medications (31.4\% used over ten different kind of drugs daily). These included analgesics (66,7\%), antidepressants (51\%), and hypnotics (9,8\%).

Characteristics of pain, according to the Geriatric Pain Measure, were investigated ${ }^{11}$. Pain was also classified according to the pathophysiological mechanism (nociceptive, neuropathic, mixed, dysfunctional or psychogenic), duration and etiology (muscle, joint, neuropathic, visceral and others).
We used the Katz scales and Lawton scales to investigate the basic activities of daily living and the instrumental activities of daily living, respectively ${ }^{12,13}$.

The reduced version (15 items) of the Geriatric Depression Scale, and the Geriatric Psychosocial Assessment ofPain-induced Depression were used to identify mood disorders ${ }^{14,15,16}$.

The self-perception of sleep (very good, good, poor and very poor) and healthy (excellent, good, fair, and poor) were also checked.

To detect the quality of sleep we used the Pittsburgh Sleep Quality Index. Patients with scores higher or equal to 5 were considered poor sleepers ${ }^{17}$.

Statistical analysis performed for the complete descriptive quantitative and qualitative variables included the Chi-square test, ANOVA test, and multiple linear regression analysis. The significance level was $95 \%-\mathrm{p}<0.05$.

\section{RESULTS}

Forty-four participants $(86.2 \%)$ had chronic nociceptive pain and the articular source was the most prevalent (86.3\%). Twenty participants $(39.2 \%)$ had pain for one year or more. Severe pain, according the Verbal Rating Scale, was seen in 29 participants $(56.9 \%)$ and the majority of them $(64.7 \%)$ had a moderate severity in a multidimensional evaluation according the Geriatric Pain Measure (Table 1).

Table 1. Characteristics of pain.

\begin{tabular}{lcc}
\hline Variables & $\mathrm{n}$ & $\%$ \\
\hline Source of pain & 17 & 33.3 \\
$\quad$ Muscle & 44 & 86.3 \\
Joint & 5 & 9.8 \\
Nerves & 2 & 4 \\
$\quad$ Others & & \\
Type of pain & 44 & 86.2 \\
Nociceptive & 5 & 9.8 \\
Neuropathic & 2 & 3.9 \\
Overlap & & \\
Duration of pain (years) & 8 & 15.7 \\
0.5-01 & 20 & 39.2 \\
01-05 & 8 & 15.7 \\
05-10 & 5 & 9.8 \\
10-20 & 10 & 19.6 \\
> 20 & & \\
Intensity of pain - VRS & 3 & 5.9 \\
Mild & 19 & 37.3 \\
Moderate & 29 & 56.9 \\
Severe & & \\
Intensity of pain - GPM & 3 & 5.9 \\
Mild & 33 & 64.7 \\
Moderate & 15 & 29.4 \\
Severe & & \\
VRS: verbal rating scale; GPM: geriatric pain measure. & \\
\hline
\end{tabular}


Almost all the participants (96.1\%) and 40 of them (78.4\%) were functionally independent according to the Activities of Daily Living and the Instrumental Activities of Daily Living scales, respectively (Table 2).

All 21 participants (41.2\%) with depression, according to the reduced Geriatric Depression Scale, had depression-induced pain. Moderate depression was most prevalent (Table 2).

Forty-two patients (82.3\%) had a perception of very good or good sleep; and their health was classified as regular in 27 participants (52.9\%) (Table 2).

However, 25 participants (49\%) were classified as "poor sleepers", according to the Pittsburgh Sleep Quality Index (Table2). We compared good and poor sleepers against: self-perception of sleep ( $p=0.010)$, number of comorbidities $(p=0.008)$, use of analgesic medications $(p=0.048)$, and antidepressant use

Table 2. Functionality, depression and sleep.

\begin{tabular}{|c|c|c|}
\hline Variables & $n$ & $\%$ \\
\hline \multicolumn{3}{|l|}{ ADLs } \\
\hline 05-06 & 49 & 96.1 \\
\hline $03-04$ & 2 & 3.9 \\
\hline \multicolumn{3}{|l|}{ IADLs } \\
\hline $26-27$ & 20 & 39.2 \\
\hline $25-21$ & 20 & 39.2 \\
\hline $20-16$ & 9 & 17.6 \\
\hline 15-10 & 2 & 3.9 \\
\hline \multicolumn{3}{|l|}{ GDS } \\
\hline No depression & 30 & 58.8 \\
\hline Possible depression & 21 & 41.2 \\
\hline \multicolumn{3}{|l|}{ GEAP } \\
\hline No depression & 21 & 41.2 \\
\hline Moderate & 21 & 41.2 \\
\hline Severe & 9 & 17.6 \\
\hline \multicolumn{3}{|l|}{ Self perception of health } \\
\hline Excellent health & 5 & 9.8 \\
\hline Good health & 19 & 37.3 \\
\hline Regular health & 27 & 52.9 \\
\hline \multicolumn{3}{|l|}{ Self perception of sleep } \\
\hline Very good sleep & 7 & 13.7 \\
\hline Good sleep & 35 & 68.6 \\
\hline Poor sleep & 9 & 17.6 \\
\hline \multicolumn{3}{|l|}{ Sleep Quality - PSQI } \\
\hline Poor sleeper & 25 & 49 \\
\hline Good sleeper & 26 & 51 \\
\hline
\end{tabular}

ADLs:activities of daily living; IADLs: instrumental activities of daily;GDS: geriatric depression scale; GEAP: geriatric psychosocial assessment of pain-induced depression; PSQI: Pittsburgh sleep quality index. $(\mathrm{p}=0.017)$, multidimensional measure of pain (Geriatric Pain Measure) $(p=0.013)$, and depression-induced pain (GEAP-p) $(\mathrm{p}<0.001)$ (Tables 3 and 4$)$.

Depression-induced pain and self-perception of sleep were variables that predicted sleep quality in this very elderly population in linear regression analysis $(\mathrm{p}<0.001)$.

\section{DISCUSSION}

There are few papers studying pain and sleep in this population of "healthy" very elderly people; however, the relationship of pain and sleep with depression is an interesting result ${ }^{18,19,20}$. We studied a population of the very elderly without dementia or cancer, and with chronic pain, who had overestimated their sleep quality and depression related to pain.

Usually, patients with chronic pain such as fibromyalgia have a poor quality of sleep, and higher prevalence of depression ${ }^{21,22,23,24}$. Indeed, the study in Newcastle showed that a poor quality of sleep was independently correlated with depression ${ }^{25}$.

Our study showed that difficulty in identifying poor sleep is most related to depression. Dew et al. ${ }^{26}$ noted that patients older than 75 years, with sleep restriction, had a higher prevalence of depression. Maglione et al. ${ }^{27}$ identified that poor sleep was also related to depression and the perception of poor sleep.

Poor sleep was seen in $49 \%$ of the very elderly patients with chronic pain in our study. Other authors have described similar findings in previous reports ${ }^{18,19,28,29}$. Chronic pain results in poor sleep in elderly people, with higher wake times after sleep onset, increased number of awakenings, and less total sleep time ${ }^{30}$. Although, sleep was identified as good for most participants, the Pittsburgh Sleep Quality Index showed a poor quality of sleep in almost half of them. This dangerous misperception has been noted by other authors ${ }^{25}$.

We found a correlation between a higher intensity of pain and poor quality of sleep. Indeed, an interesting study, named MOBILIZE, showed that poor sleep quality is related to multiple locations of pain in the body ${ }^{31}$.

Many diseases were associated with a worse quality of sleep, as well. The National Sleep Foundation Survey demonstrated that $41 \%$ of patients with four or more diseases had poorer sleep when compared to $10 \%$ of patients without diseases ${ }^{32}$. Usually, very elderly people take a lot of pills

Table 3. Relationship between sleep quality and quantitative variables.

\begin{tabular}{|c|c|c|c|c|c|}
\hline \multirow{2}{*}{ Variable } & \multicolumn{2}{|c|}{ Good sleeper $(n=26)$} & \multicolumn{2}{|c|}{ Poor sleeper $(n=25)$} & \multirow{2}{*}{$p$-value } \\
\hline & Average & DP & Average & DP & \\
\hline GPM & 53.4 & 19.73 & 66.12 & 15.15 & .013 \\
\hline Depression due to pain (GEAP) & 4.88 & 3.02 & 9.04 & 4.77 & .001 \\
\hline Number of diseases & 4.15 & 1.76 & 5.76 & 2.33 & .008 \\
\hline Number of medications & 6.62 & 2.52 & 9.44 & 3.25 & .001 \\
\hline
\end{tabular}

GPM: geriatric pain measure; GEAP: geriatric psychosocial assessment of pain-induced depression. 
Table 4.- Relationship between sleep quality and qualitative variables.

\begin{tabular}{|c|c|c|c|c|c|c|c|}
\hline \multirow{2}{*}{ Variable } & \multicolumn{2}{|c|}{ Good sleeper } & \multicolumn{2}{|c|}{ Poor sleeper } & \multicolumn{2}{|c|}{ Total } & \multirow{2}{*}{$\mathrm{p}$-value } \\
\hline & $\mathrm{n}$ & $\%$ & $\mathrm{n}$ & $\%$ & $\mathrm{n}$ & $\%$ & \\
\hline \multicolumn{8}{|c|}{ Analgesics use } \\
\hline No & 12 & $46 \%$ & 5 & $20 \%$ & 17 & $33 \%$ & \\
\hline Yes & 14 & $54 \%$ & 20 & $80 \%$ & 34 & $67 \%$ & 0.048 \\
\hline \multicolumn{8}{|c|}{ Antidepressants use } \\
\hline No & 17 & $65 \%$ & 8 & $32 \%$ & 25 & $49 \%$ & \\
\hline Yes & 9 & $35 \%$ & 17 & $68 \%$ & 26 & $51 \%$ & 0.017 \\
\hline \multicolumn{8}{|c|}{ Self-perception of sleep } \\
\hline Very good & 7 & $27 \%$ & 0 & $0 \%$ & 7 & $14 \%$ & \\
\hline Good & 18 & $69 \%$ & 17 & $68 \%$ & 35 & $69 \%$ & \\
\hline Poor & 1 & $4 \%$ & 8 & $32 \%$ & 9 & $18 \%$ & 0.010 \\
\hline \multicolumn{8}{|c|}{ Depression due to pain (GEAP) } \\
\hline None & 15 & $58 \%$ & 6 & $24 \%$ & 21 & $41 \%$ & \\
\hline Moderate & 10 & $38 \%$ & 11 & $44 \%$ & 21 & $41 \%$ & \\
\hline Severe & 1 & $4 \%$ & 8 & $32 \%$ & 9 & $18 \%$ & 0.03 \\
\hline
\end{tabular}

GEAP: geriatric psychosocial assessment of pain-induced depression.

for their many ailments. In fact, poor sleep is associated with the greater number of diseases and quantity of pills. Other authors have shown that older people with chronic pain and poor quality of sleep take more hypnotics ${ }^{19}$.

A few limitations of our study must be highlighted: such as the limited number of patients and the subjective analysis of sleep. Another limitation of this research is that we did not study factors that can cause poor sleep quality, such as the use of medication, clinical comorbidities, and sleep disturbances. This is understandable, considering the difficulties of finding very elderly people without dementia or cancer, as well as the expense and difficulty in having the participants sleep in a sleep laboratory. Indeed, these geriatrics may have different expectations of sleep and wakefulness, and there is an association between subjective memory complaints and comorbidity such as pain ${ }^{25,33}$. It is possible that these could have contributed to our findings.

It is extremely valuable to identify, in very elderly people without dementia, the correlation between chronic pain, poor sleep and depression. Although, there is an extreme impact of these factors during aging, they are highly underestimated in family, patients and health professionals. Longitudinal studies to clarify and highlight this prevalent aspect of aging are necessary.

\section{References}

1. Latham J, Davis BD. The socioeconomic impact of chronic pain. Disabil Rehabil. 1994;16(1):39-44. doi:10.3109/09638289409166435

2. Roehrs T, Roth T. Sleep and pain: interaction of two vital functions. Semin Neurol. 2005;25(1):106-16. doi:10.1055/s-2005-867079

3. Neikrug AB, Ancoli-Israel S. Sleep disorders in the older adult - a mini-review. Gerontology. 2010;56(2):181-9. doi:10.1159/000236900

4. Helme RD, Gibson SJ. The epidemiology of pain in elderly people. Clin Geriatr Med. 2001;17(3):417-31. doi:10.1016/S0749-0690(05)70078-1

5. Satghare P, Chong SA, Vaingankar J, Picco L, Abdin E, Chua BY, Subramaniam M. Prevalence and correlates of pain in people aged 60 years and above in Singapore: results from the WiSE study. Pain Res Manag. 2016;2016:7852397. doi:10.1155/2016/7852397

6. Chen B, Li L, Donovan C, Gao Y, Ali G, Jiang Y et al. Prevalence and characteristics of chronic body pain in China: a national study. Springerplus. 2016;5(1):938. doi:10.1186/s40064-016-2581-y

7. Smith MT, Haythornthwaite JA. How do sleep disturbance and chronic pain inter-relate? Insights from the longitudinal and cognitive-behavioral clinical trials literature. Sleep Med Rev. 2004;8(2):119-32. doi:10.1016/S1087-0792(03)00044-3
8. Abdulla A, Adams N, Bone M, Elliott AM, Gaffin J, Jones D, et al. Guidance on the management of pain in older people. Age Ageing. 2013;42 Suppl 1:i1-57. doi:10.1093/ageing/afs199

9. Santos FC, Moraes NS, Pastore A, Cendoroglo MS. Chronic pain in long-lived elderly: prevalence, characteristics, measurements and correlation with serum vitamin D level. Rev Dor. 2015;16(3):171-5. doi:10.5935/1806-0013.20150034

10. Merskey NB, editor. Classification of chronic pain: descriptions of chronic pain syndromes and definitions of pain terms prepared by the International Association for the Study of Pain. 2nd ed. Seattle: Press I; 1994.

11. Gambaro RC, Santos FC, Castro KB, Cendoroglo MS. [Questionnaire of pain in geriatrics: adaptation proposal for portuguese language of GPM]. Rev Bras Reum. 2009;10(1):62-5.

12. Katz S, Akpom CA. A measure of primary sociobiological functions. Int J Health Serv. 1976;6(3):493-508. doi:10.2190/UURL-2RYU-WRYD-EY3K

13. Lawton MP, Brody EM. Assessment of older people: self-maintaining and instrumental activities of daily living. Gerontologist. 1969;9(3):179-86. doi:10.1093/geront/9.3_Part_1.179

14. Yesavage JA. Geriatric depression scale. Psychopharmacol Bull. 1988;24(4):709-11. 
15. Wilson JE. A geriatric psychosocial assessment of pain-induced depression [dissertation]. Minneapolis: Walden University; 2011.

16. Almeida CBL, Santos FC. Depressão dor-induzida em idosos: validação das propriedades psicométricas da versão brasileira do "Geriatric Emotional Assessment of Pain" - "GEAP-b" [dissertação]. São Paulo: Universidade Federal de São Paulo; 2015.

17. Buysse DJ, Reynolds CF, 3rd, Monk TH, Berman SR, Kupfer DJ. The Pittsburgh Sleep Quality Index: a new instrument for psychiatric practice and research. Psychiatry Res. 1989;28(2):193-213. doi:10.1016/0165-1781(89)90047-4

18. Zarit SH, Griffiths PC, Berg S. Pain perceptions of the oldest old: a longitudinal study. Gerontologist. 2004;44(4):459-68. doi:10.1093/geront/44.4.459

19. Jakobsson U, Hallberg IR, Westergren A. Overall and health related quality of life among the oldest old in pain. Qual Life Res. 2004;13(1):125-36. doi:10.1023/B:QURE.0000015286.68287.66

20. Giron MS, Forsell Y, Bernsten C, Thorslund M, Winblad B, Fastbom J. Sleep problems in a very old population: drug use and clinical correlates. J Gerontol A Biol Sci Med Sci. 2002;57(4):M236-40. doi:10.1093/gerona/57.4.M236

21. Casanueva B, García-Fructuoso F, Belenguer R, Alegre C, Moreno-Muelas JV, Hernández JL et al. The Spanish version of the 2010 American College of Rheumatology Preliminary Diagnostic Criteria for fibromyalgia: reliability and validity assessment. Clin Exp Rheumatol. 2016;34(2 Suppl 96):S55-8.

22. Von Korff M, Dworkin SF, Le Resche L, Kruger A. An epidemiologic comparison of pain complaints. Pain. 1988;32(2):173-83. doi:10.1016/0304-3959(88)90066-8

23. Lamb SE, GuralnikJM, Buchner DM, Ferrucci LM, Hochberg MC, Simonsick EM, et al. Factors that modify the association between knee pain and mobility limitation in older women: the Women's Health and Aging Study. Ann Rheum Dis. 2000;59(5):331-7. doi:10.1136/ard.59.5.331

24. Benca RM, Ancoli-Israel S, Moldofsky H. Special considerations in insomnia diagnosis and management: depressed, elderly, and chronic pain populations. J Clin Psychiatry. 2004;65 Suppl 8:26-35.
25. Anderson KN, Catt M, Collerton J, Davies K, Zglinicki T, Kirkwood TB et al. Assessment of sleep and circadian rhythm disorders in the very old: the Newcastle 85+ Cohort Study. Age Ageing. 2014;43(1):57-63. doi:10.1093/ageing/aft153

26. Dew MA, Reynolds CF 3rd, Monk TH, Buysse DJ, Hoch CC, Jennings R et al. Psychosocial correlates and sequelae of electroencephalographic sleep in healthy elders. J Gerontol. 1994;49(1):8-18. doi:10.1093/geronj/49.1.P8

27. Maglione JE, Ancoli-Israel S, Peters KW, Paudel ML, Yaffe K, Ensrud KE et al. Subjective and objective sleep disturbance and longitudinal risk of depression in a cohort of older women. Sleep. 2014l:37(7):1179-87. doi:10.5665/sleep.3834.

28. Sampaio RA, Sewo Sampaio PY, Yamada M, Tsuboyama T, Arai H. Self-reported quality of sleep is associated with bodily pain, vitality and cognitive impairment in Japanese older adults. Geriatr Gerontol Int. 2014;14(3):628-35. doi:10.1111/ggi.12149

29. Lunde LH, Pallesen S, Krangnes L, Nordhus IH. Characteristics of sleep in older persons with chronic pain: a study based on actigraphy and self-reporting. Clin J Pain. 2010;26(2):132-7. doi:10.1097/AJP.0b013e3181b61923

30. Blågestad T, Pallesen S, Lunde LH, Sivertsen B, Nordhus IH, Gronli J. Sleep in older chronic pain patients: a comparative polysomnographic study. Clin J Pain. 2012;28(4):277-83. doi:10.1097/AJP.0b013e3182313899

31. Chen Q, Hayman LL, Shmerling RH, Bean JF, Leveille SG. Characteristics of chronic pain associated with sleep difficulty in older adults: the Maintenance of Balance, Independent Living, Intellect, and Zest in the Elderly (MOBILIZE) Boston study. J Am Geriatr Soc. 2011;59(8):1385-92. doi:10.1111/j.1532-5415.2011.03544.x

32. Foley D, Ancoli-Israel S, Britz P, Walsh J. Sleep disturbances and chronic disease in older adults: results of the 2003 National Sleep Foundation Sleep in America Survey. J Psychosom Res. 2004;56(5):497-502. doi:10.1016/j.jpsychores.2004.02.010

33. Pedro MC, Mercedes MP, Ramón LH, Borja MR. Subjective memory complaints in elderly: relationship with health status, multimorbidity, medications, and use of services in a population-based study. Int Psychogeriatr. 2016;29:1-14. doi:10.1017/S104161021600106X 